\title{
Expression, purification and characterization of a recombinant fusion protein based on the human papillomavirus-16 E7 antigen
}

\author{
Milaid Granadillo, Aileen Batte, Victoria M Lugo, Alexis Musacchio, Mónica Bequet-Romero, Lázaro Betancourt, \\ Vladimir Besada, Luis Javier, Raychel Molina, Viviana Falcón and Isis Torrens*
}

\begin{abstract}
A fusion protein comprising a cell penetrating and immunostimulatory peptide corresponding to residues 32 to 51 of the Limulus polyphemus protein linked to human papillomavirus (HPV)-16 E7 antigen (LALF 32-51 $_{1}$-E7) was expressed in E. coli BL21 (DE3) cells. The recombinant protein in E. coli accounted for approximately $18 \%$ of the total cellular protein and purified with a single affinity chromatographic step. Yields of approximately $38 \mathrm{mg}$ purified LALF $32-51$-E7 per liter of induced culture was obtained with an overall $52 \%$ recovery and constitutes a promising setting for the future production and scaling-up. Purified protein was characterized as soluble aggregates with molecular weight larger than $670 \mathrm{kDa}$, which is considered an important property to increase the immunogenicity of an antigen preparation. The recombinant fusion protein $\mathrm{LALF}_{32-51}-\mathrm{E} 7$ will be a promising vaccine candidate for the treatment of HPV-16 related malignancies.
\end{abstract}

Keywords: Fusion protein, Human papillomavirus-16, E7 antigen, LALF ${ }_{32-51}$, E. coli

\section{Background}

Cervical cancer represents the second most frequent cancer in women (zur Hausen 2009). Today it is very well established that so-called high-risk human papillomavirus (HPV) infections, particularly those related to HPV-16, cause cervical cancer (zur Hausen 2002). The availability of preventive vaccines against HPVs represents a milestone in the prevention of this infection (Harper et al. 2006), but no effective therapeutic vaccine or immunological treatment exists for individuals already infected or for the 470,000 women that develop highgrade dysplasia, carcinoma in situ, and cervical cancer each year.

The oncogenic potential of HPV-16 is mainly ascribed to the viral oncoprotein E7, which has been shown to interact with a variety of cellular proteins (Munger et al. 2001). Moreover, being expressed in all the cervical tumors and in precancerous lesions, the E7 protein represents a specific target for immunotherapy (zur Hausen 2002).

\footnotetext{
* Correspondence: isis.torrens@cigb.edu.cu

Center for Genetic Engineering and Biotechnology, P.O. Box 6162, Cubanacan, Playa, Havana 10600, Cuba
}

\section{Springer}

We designed a fusion protein comprising a cell penetrating and immunostimulatory peptide corresponding to residues 32 to 51 of the Limulus polyphemus protein $\left(\mathrm{LALF}_{32-51}\right)$ linked to HPV-16 E7 antigen ( $\mathrm{LALF}_{32-51-E 7)}$ and selected $E$. coli as protein expression systems by its relative simplicity, its inexpensive and fast high-density cultivation, the well known genetics and the large number of compatible tools available for biotechnology (Jana and Deb 2005).

In a previous paper we describes some results related the biological properties of this fusion protein, a promissory vaccine candidate for the treatment of HPV-16-related malignancies (Granadillo et al. 2011). Here we describe the expression and purification and some results concerning the characterization of this recombinant fusion protein. We demonstrated that $\mathrm{LALF}_{32-51}$-E7 is highly expressed in $E$. coli BL21 (DE3) and easily purified with a single chromatographic step with a high purity. Non-optimized yields obtained by us are in order of $38 \mathrm{mg} / \mathrm{l}$ of bacterial culture, a very promising setting for the future production and scaling-up. We also show that the protein is obtained in a highly aggregated form, a property that is considered very 
important to increase the immunogenicity of an antigen preparation.

\section{Results \\ Bacterial expression and purification of $\mathrm{LALF}_{32-51}-\mathrm{E7}$ fusion protein}

The DNA sequence of kanamycin resistance gene (KanR) was amplified by PCR from the corresponding gene of a reliable plasmid template, purified and cloned into pPEPE7M-7 vector (Granadillo et al. 2011), which expresses the 134 amino acid $\mathrm{LALF}_{32-51}$-E7 fusion protein. After corroborating that the KanR gene was successfully cloned, BL21 (DE3) cells were transformed with the pPEPE7M-7K plasmid and induced for expression obtaining approximately $7 \mathrm{~g} / \mathrm{l}$ of biomass at the end of the fermentation process. As shown in Figure $1 \mathrm{~A}$, lane 1, $\mathrm{LALF}_{32-51}$-E7 accounted for approximately $18 \%$ of the total cellular protein and migrated as an approximately $24 \mathrm{kDa}$ protein in $15 \%$ sodium dodecyl sulfate polyacrilamide electrophoresis (SDS-PAGE). The fusion protein was located in the insoluble fraction after cell disruption (Figure 1A, lane 3). This protein was solubilized from bacterial pellet using $6 \mathrm{M}$ urea (Figure 1A, lane 4) and further purified by immobilized metal-ion affinity chromatography (IMAC) up to $94 \%$ purity (Figure 1A, lane 9). The fusion protein was recognized by an anti-HPV-16 E7 mouse monoclonal antibody in Western blot (Figure 1B). The $300 \mathrm{mM}$ imidazole eluate contains a major $24 \mathrm{kDa} \mathrm{LALF}_{32-51}$-E7 band and high molecular weight $(\mathrm{MW})$ aggregates of this same protein, as shown by Western Blot analysis (Figure 1B, lanes 8 and 9). Yields of approximately $38 \mathrm{mg}$ purified $\mathrm{LALF}_{32-51}$-E7 per liter of induced culture was obtained with an overall $52 \%$ recovery (Table 1). The IMAC-purified fusion protein was further analyzed by size exclusion analytic HPLC in Superdex 200 10/300 GL. A major peak eluting in the void volume of the column and accounting for $100 \%$ of the applied protein was obtained (Figure 1C). According to the used column calibration standard, this peak appears to contain soluble aggregates with MW larger than $670 \mathrm{kDa}$.

\section{Transmission electron microscopy studies}

In order to corroborate if the LALF $_{32-51}$-E7 fusion protein was expressed as inclusion bodies, ultrastructural studies were performed. As expected, transmission electron microscopy study of cells harboring pPEPE7M-7K indicated that the fusion protein is produced as cytoplasmic inclusion bodies (Figure 2A).

To characterize the purified fusion protein, preparations of LALF $_{32-51}$-E7 were analyzed by negative staining. The Figure $2 \mathrm{~B}$ shows representative electron microscopy micrograph of the $\mathrm{LALF}_{32-51}$-E7 preparation. The protein appears as aggregates of different shape and size.

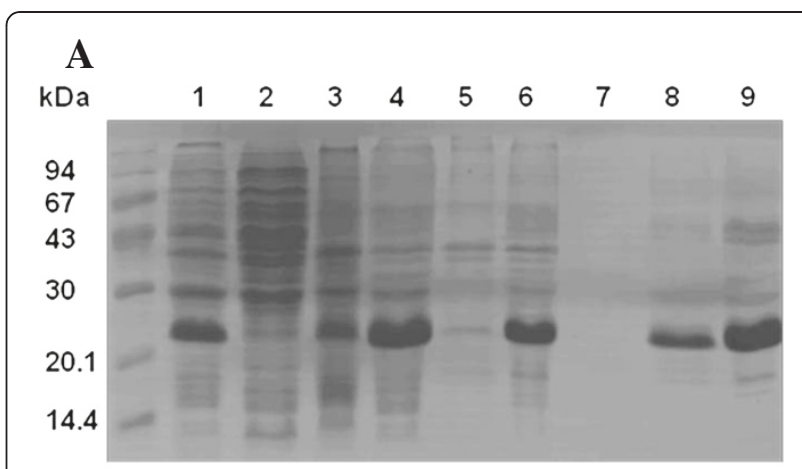

B

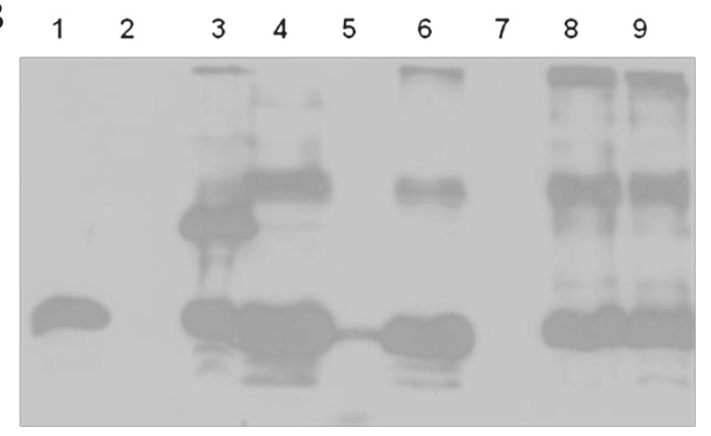

C

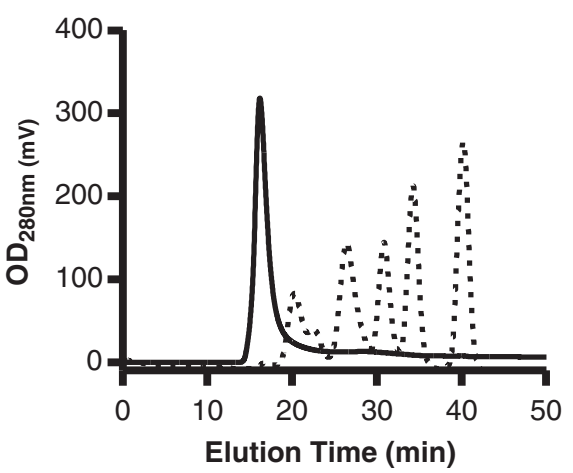

Figure 1 Expression and purification of the fusion protein LALF $_{\text {32-51-E7. (A) SDS-PAGE (15\%). (B) Western Blot using anti-HPV-16 }}$ E7 monoclonal antibody: initial crude extract of $E$. coli proteins containing the expressed (about 18\%) fusion protein $\mathrm{LALF}_{32-51}$-E7 (lane 1); soluble fraction after cell disruption (lane 2); insoluble fraction after cell disruption (lane 3); soluble fraction after treatment with $6 \mathrm{M}$ urea (lane 4); insoluble fraction after treatment with $6 \mathrm{M}$ urea (lane 5); IMAC purification, initial sample (lane 6); IMAC purification, wash with 10 mM imidazole (lane 7); IMAC purification, elution with 300 mM imidazole (lane 8); 300 mM imidazole elution fraction after desalting (lane 9). Molecular mass markers are indicated on the left. (C) Analytical

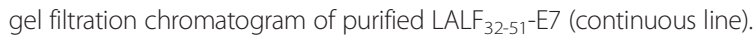
Dash line is representative of the retention time for (from left to right) bovine thyroglobulin (670 kDa), bovine gamma globulin (158 kDa), ovalbumin (44 kDa), myoglobin (17 kDa) and vitamin B-12 (1.35 kDa).

\section{Mass spectrometry analysis}

According to the gene sequence, $\mathrm{LALF}_{32-51}$-E7 is synthesized as a protein of 134 amino acids containing a hexa-histidine tag at the C-terminus, with a theoretical mass value of 15867.85 Da. ESI-MS of reduced and carboamidomethylated 
Table 1 Summary of LALF $_{32-51}$-E7 purification (from dry weight of the biomass $(0.75 \mathrm{~g} / \mathrm{l})$ )

\begin{tabular}{|c|c|c|c|c|c|c|c|}
\hline Step & $\begin{array}{l}\text { Volume } \\
(\mathrm{mL})\end{array}$ & $\begin{array}{l}\text { Total protein concentration } \\
\qquad(\mathrm{mg} / \mathrm{mL})\end{array}$ & $\begin{array}{l}\text { Purity } \\
(\%)^{a}\end{array}$ & $\begin{array}{c}\text { Amount of } \\
\text { LALF }_{32-51}-\mathrm{E} 7 \\
\text { (mg) }\end{array}$ & $\begin{array}{l}\text { Purification } \\
\text { fold }\end{array}$ & $\begin{array}{l}\text { Step yield } \\
(\%)\end{array}$ & $\begin{array}{l}\text { Overall yield } \\
(\%)\end{array}$ \\
\hline Initial crude extract & 30 & 5.85 & 18 & 31.59 & 1 & 100 & 100 \\
\hline $\begin{array}{l}\text { Insoluble fraction after cell } \\
\text { disruption }\end{array}$ & 30 & 2.33 & 32 & 22.37 & 1.7 & 71 & 71 \\
\hline Solubilization & 15 & 3.07 & 45 & 20.72 & 1.4 & 93 & 66 \\
\hline IMAC elution & 25 & 0.75 & 94 & 17.63 & 2 & 85 & 56 \\
\hline Desalting & 35 & 0.5 & 94 & 16.45 & 1 & 93 & 52 \\
\hline
\end{tabular}

${ }^{a}$ Determined by densitometry.

The protein concentration was determined by Bio-Rad protein assay (Bradford 1976), using bovine serum albumin as the reference standard.

protein (rcm- LALF $_{32-51-E 7)}$ gave a major signal of 15736.90 Da in mass (Figure 3A), which is in good agreement with the theoretical value $(15736.65 \mathrm{Da})$ calculated for the sequence starting from the second amino acid (alanine, abbreviated A in Figure 4). The major signal obtained differs in 130.95 mass units with respect to the expected theoretical mass of entire protein (15867.85 Da), indicating a full processing of the initiation methionine from the protein.

To further verify the identity of the molecule, the protein was enzymatically digested with trypsin, and generated fragments were analyzed by mass spectrometry. Identified peptides accounted for $93 \%$ of the entire sequence of $\mathrm{LALF}_{32-51}$-E7 (Table 2). Undetected peptides corresponded to fragments with less than 3 amino acids which are out of the mass range analysis of the mass spectrometer (400-2000 Th). ESI-MS/MS sequencing of $\mathrm{N}$ - and C-terminal suspected peptides confirm the lack of the initiation methionine (Figure $3 \mathrm{~B}$ ) and the presence of the six-His-tag, respectively (Figure 3C).

\section{Discussion}

In this paper, we describe the expression, purification and some results related to the characterization of $\mathrm{LALF}_{32-51^{-}}$ E7 fusion protein; a promising vaccine candidate for the treatment of HPV-16 related malignancies. Antigen design was based on mutated version of viral HPV-16 E7 antigen bearing a base substitution of $\mathrm{T}$ by $\mathrm{G}$ in the triplet encoding cysteine at position 24 (substitution of Cys to Gly) in order to disrupt their binding to protein $\mathrm{Rb}$ (Munger et al. 1989; Barbosa et al. 1990; Jones et al. 1990), in this way reducing possible regulatory objections in the future development of a human vaccine candidate. To improve safety, and since the ampicillin resistance gene (AmpR) is precluded for use in humans, we introduced the KanR gene as a selectable marker of our final expression vector pPEPE7M-7K. The KanR gene is the antibiotic resistance marker often used while the AmpR is not acceptable due to concerns with hyper reactivity of some patients to $\beta$ lactam antibiotics (Williams et al. 2009).
It is well documented that a key aspect influencing on the expression of heterologous proteins in E. coli cytoplasm is the selection of host strain (Sorensen and Mortensen 2005). In this sense E. coli BL21 (DE3) is the most common host and has proven outstanding in standard recombinant expression application, is able to grow vigorously in minimal media but however non-pathogenic and unlikely to survive in host tissues and cause disease (Chart et al. 2000). In this paper, we show that the fusion protein LALF $_{32-51}$-E7 is highly expressed (18\%) in E. coli BL21 (DE3). In agreement with our results other researchers have expressed efficiently recombinant fusion proteins for therapeutic purposes based on HPV-16 E7 antigen in E. coli (Chu et al. 2000; Preville et al. 2005; Liu et al. 2008). In this work we also show that $\mathrm{LALF}_{32-51}$-E7 was easily purified with a single affinity chromatographic step (up to 94\% purity) that can be followed by other polishing ones (i.e. gel filtration) if manufactured for human vaccine purposes. The non-optimized yields obtained by us are in order of $38 \mathrm{mg}$ of purified $\mathrm{LALF}_{32-51}$-E7 per liter of induced culture, a promising figure in terms of production and scaling-up. This study also reports that the fusion protein was obtained highly aggregated, a property that could be convenient to enhance immunogenicity for an antigen preparation. Other researchers have reported that while low MW aggregates such as dimers and trimers appear inefficient in inducing immune responses, large multimers whose MW exceeds $100 \mathrm{kDa}$ are efficient inducers of immune responses (Rosenberg 2006). As our aim was to obtain a highly immunogenic E7 preparation, we did not focus on obtaining aggregates of identical shape and size considering that particles of different size can be taken up by different types of antigen presenting cells, such as dendritic cells, macrophages and polymorphonuclear leukocytes, sustaining a more potent immune response (Oyewumi et al. 2010).

In this study we also characterized the $\mathrm{LALF}_{32-51}$-E7 fusion protein by mass spectrometry. $\mathrm{LALF}_{32-51}-\mathrm{E} 7$ is a 134 amino acids protein with a hexa-histidine tag at the $\mathrm{C}$ terminus and a theoretical molecular mass of 15867.85 Da. The mass spectrometry analyses were in good agreement with the theoretical molecular mass value of the full length 

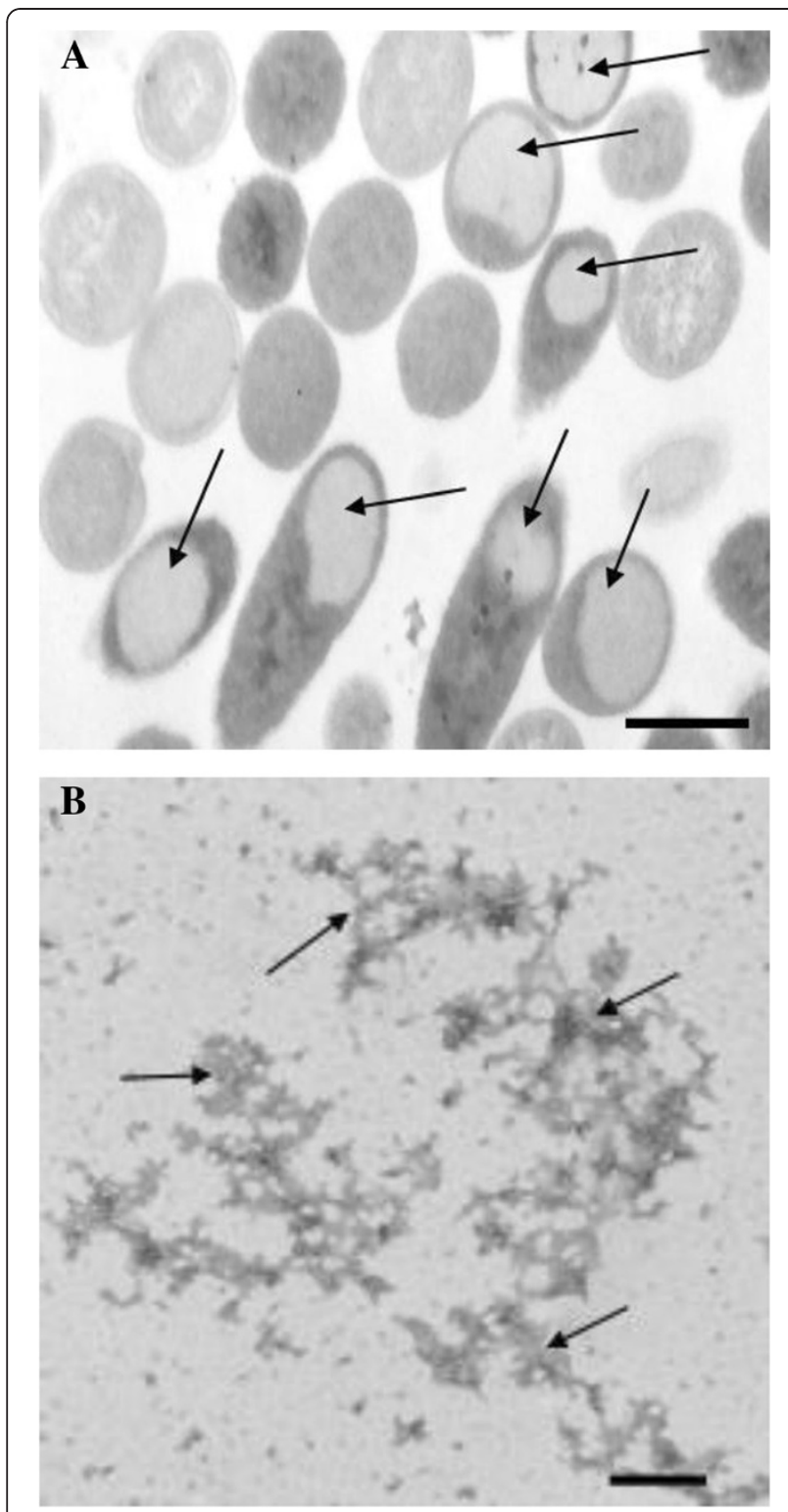

Figure 2 Transmission electron micrographs.

(A) Microphotograph showing at ultrastructural level the presence of inclusion bodies inside the E. coli transformed cell, corresponding to the $L_{A L F}{ }_{32-51}-E 7$ fusion protein. The bar represents $500 \mathrm{~nm}$. (B) Electron micrograph of the negatively stained $\mathrm{LALF}_{32-51}-\mathrm{E} 7$ preparation sample showing aggregates of different shape and size. The bar represents $200 \mathrm{~nm}$.

gene product without the $\mathrm{N}$-terminal methionine and verified the identity of the molecule.

Although the theoretical mass value of $\mathrm{LALF}_{32-51}$-E7 is approximately $16 \mathrm{kDa}$, the protein migrated in SDS-PAGE under reducing conditions as an approximately $24 \mathrm{kDa}$ protein that is larger in size than predicted. This abnormal migration pattern has been previously reported for the HPV-16 E7 protein, and is attributable to their high content of acidic amino acid residues (Armstrong and Roman 1993; Bolhassani et al. 2008).

The $E$. coli expressed proteins represent a well-studied and cost-effective means for the production of vaccines. Our vaccine candidate represents not only a good substrate for antigen-presenting cell uptake and processing, but also a cost-effective promising approach for developing a HPV therapeutic vaccine. A generation of new low-cost HPV vaccines could represent the only possibility for women living in developing countries to gain access to HPV vaccination programs to prevent or treat pre-cancerous lesions and cancer.

\section{Conclusions}

This is a report of a non-optimized process about the expression, purification and characterization of a recombinant fusion protein that is a cost-effective promising approach for developing a HPV therapeutic vaccine.

\section{Methods}

\section{Fusion protein expression vector}

The AmpR gene of the plasmid pPEPE7M-7 (Granadillo et al. 2011) that containing the recombinant $\mathrm{LALF}_{32-51}$-E7 fusion protein was interrupted by digestion with ScaI and a DNA fragment containing the KanR gene was cloned in this plasmid. The KanR gene was PCR amplified from pUC4K using two primers. The forward primer 5' CAG CTG GCC ACG TTG TGT CTC AAA ATC 3' contains a PvuII site as well as the reverse primer 5' CAG CTG TTC AAC AAA GCC GCC GTC CC 3'. The PCR product was digested with PvuII, purified and ligated to pPEPE7M-7 which had been cut with ScaI. The KanR gene orientation was verified by ClaI digestion. Clones resulting in bands of approximately 3.2 and $1.3 \mathrm{~kb}$ have opposite orientation respect to the target gene and clones resulting in bands of 2.5 and $2 \mathrm{~kb}$ have the same orientation respect to the target gene. We selected the clone in which the KanR gene has opposite orientation respect to the target gene and was designated pPEPE7M-7K (Figure 4).

\section{Expression and purification of $\mathrm{LALF}_{32-51}-\mathrm{E7}$}

BL21 (DE3) cells transformed with pPEPE7M-7K were inoculated in $500 \mathrm{ml}$ of LB medium containing kanamy$\operatorname{cin}(50 \mu \mathrm{g} / \mathrm{ml})$ and incubated for $6 \mathrm{~h}$ at $37^{\circ} \mathrm{C}$ in a shaker. This culture were used to inoculate a $5 \mathrm{l}$ fermentor (B.E. Marubishi, Japan) containing M9 salt medium enriched with $10 \mathrm{~g} / \mathrm{l}$ casein hydrolysate, $0.011 \mathrm{~g} / \mathrm{l} \mathrm{CaCl}_{2} \cdot 2 \mathrm{H}_{2} \mathrm{O}$, $0.246 \mathrm{~g} / 1 \mathrm{MgSO}_{4} \cdot 7 \mathrm{H}_{2} \mathrm{O}, 2 \mathrm{~g} / \mathrm{l}$ glucose and $0.05 \mathrm{~g} / \mathrm{l} \mathrm{kana-}$ mycin. After three h, $3 \beta$-indole-acrylic acid was added to a final concentration of $0.04 \mathrm{~g} / \mathrm{l}$ and the culture was grown for another $15 \mathrm{~h}$ to obtain as much possible recombinant protein as insoluble inclusion bodies according to the standard production protocol for $E$ coli based technology implemented in our institute. The fermentation parameters 

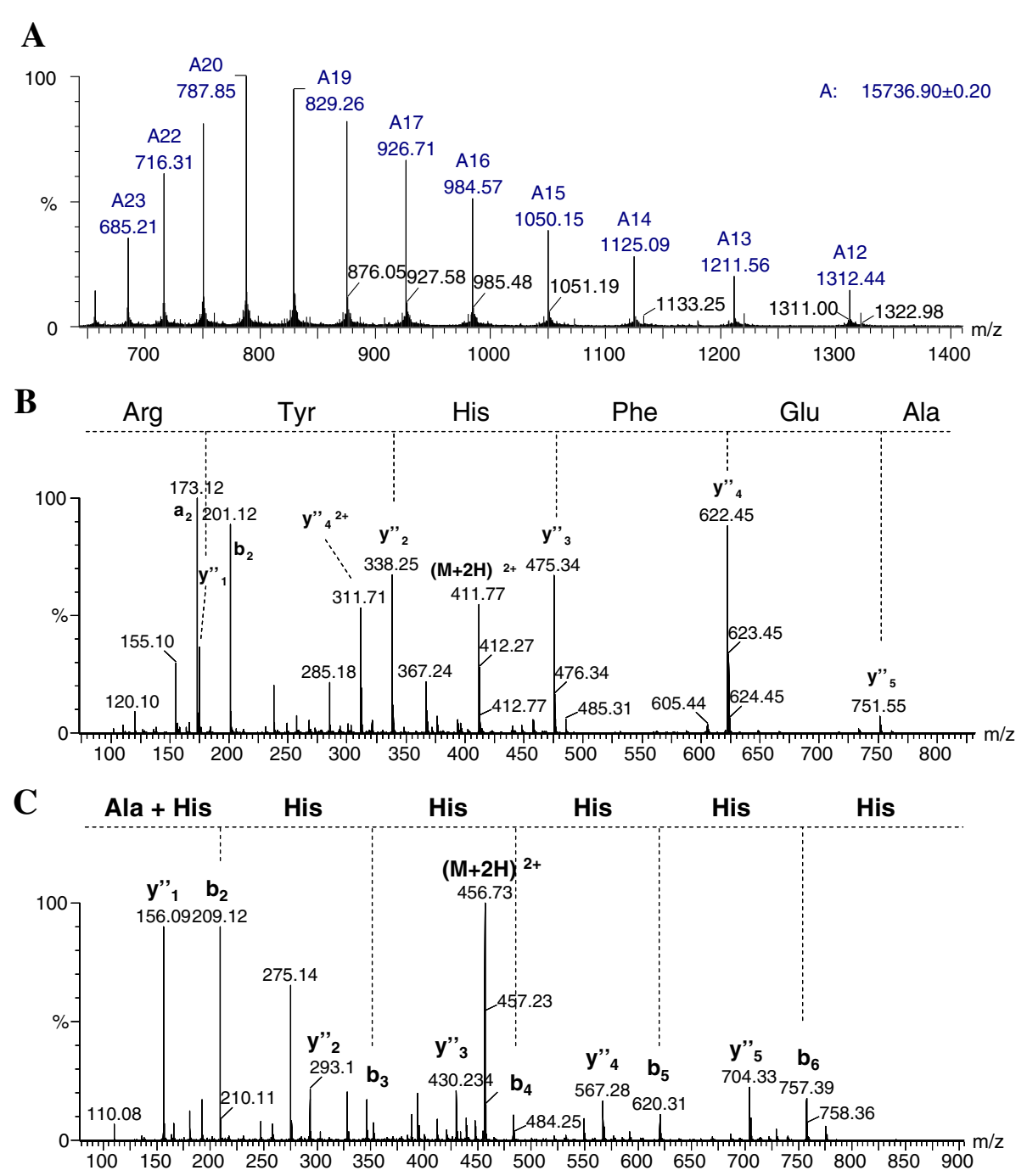

Figure 3 Mass spectrometry analysis. (A) ESI mass spectra of $r c m-L A L F_{32-51}-E 7$. (B) Sequencing by ESI-MS/MS of the peptide of $\mathrm{m} / \mathrm{z} 411.70$

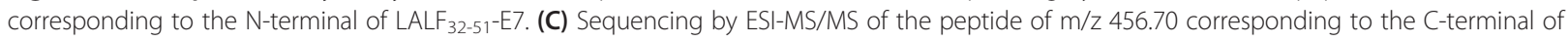

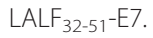

were $\mathrm{pH} 7.0,37^{\circ} \mathrm{C}, 350 \mathrm{rpm}$ and $1.0 \mathrm{vvm}$ aeration rate, operated in a batch mode.

Cells were harvested by centrifugation at $15000 \mathrm{~g}$ for $20 \mathrm{~min}$ at $4^{\circ} \mathrm{C}$. Then, $3 \mathrm{~g}$ of cellular biomass was resuspended in $30 \mathrm{ml}$ of rupture buffer $\left(50 \mathrm{mM} \mathrm{NaH} \mathrm{PO}_{4}\right.$, $300 \mathrm{mM} \mathrm{NaCl}, \mathrm{pH}$ 8.0) at a ratio of biomass/buffer of 1:10. The biomass was disrupted in French Press (Othake, Japan) at 1500 bar, with two passes on $4^{\circ} \mathrm{C}$. After centrifugation at $15000 \mathrm{~g}$ for $30 \mathrm{~min}$ at $4^{\circ} \mathrm{C}$, the pellet was recovered and the recombinant protein was totally solubilized in $6 \mathrm{M}$ urea in carbonate-bicarbonate buffer $\mathrm{pH}$ 10.6. Cell debris was removed by centrifugation at $15000 \mathrm{~g}$ for $30 \mathrm{~min}$ at $4^{\circ} \mathrm{C}$ and the soluble fraction containing the fusion protein, that have a six-histidine C-terminus tail for purification purposes, was recovered. Due to the recombinant protein was totally solubilized in $6 \mathrm{M}$ urea in carbonate-bicarbonate buffer $\mathrm{pH} 10.6$ and not in other buffers at lowers $\mathrm{pH}$ and at different urea concentrations (data not shown), the purification of the protein was necessarily conducted in carbonate-bicarbonate buffer $\mathrm{pH}$ 10.6. The soluble fraction was diluted in equal volume of $1 \mathrm{M} \mathrm{NaCl}$ and loaded onto a $22 \mathrm{ml} \mathrm{His-Select}{ }^{\circledR}$ Nickel Affinity Gel (Sigma, Catalog number P6611) equilibrated with loading buffer (3 M urea and $0.5 \mathrm{M} \mathrm{NaCl}$ in carbonate-bicarbonate $\mathrm{pH}$ 10.6). The column was then washed with loading buffer containing $10 \mathrm{mM}$ imidazole and the protein of interest was eluted with $300 \mathrm{mM}$ imidazole. The eluted IMAC fraction $(25 \mathrm{ml})$ was further loading onto a HiPrep 26/10 desalting column (GE Healthcare) equilibrated with $10 \mathrm{mM}$ Tris $\mathrm{pH} 8.0$ renaturation buffer and following the manufacturer's instructions. In this chromatographic step the protein was refolded because the 


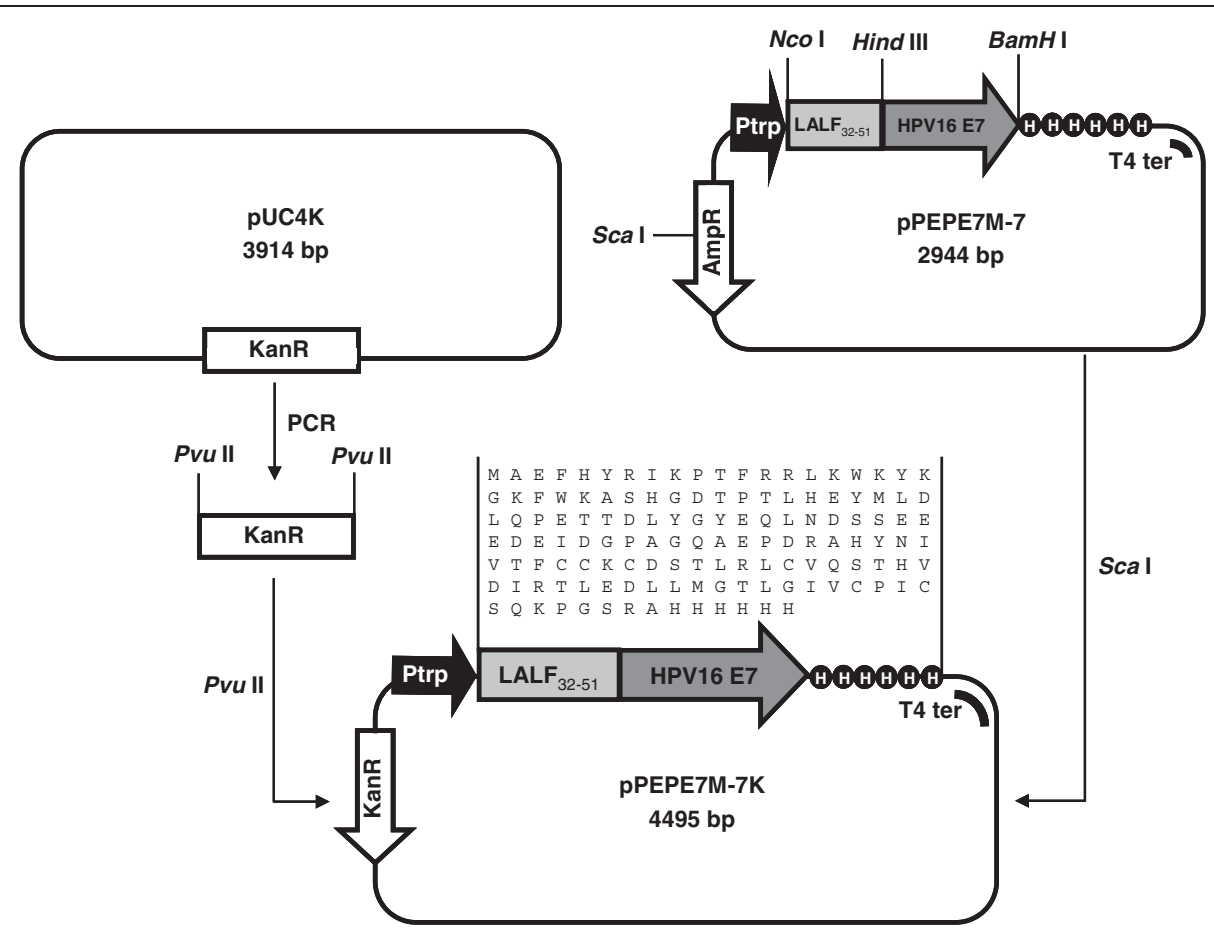

Figure 4 Schematic representation of pPEPE7M-7K construction for the expression of the LALF $_{32-51}-\mathrm{E} 7$ fusion protein.

urea and imidazole were totally removed. The peak fractions containing LALF $_{32-51}$-E7 protein were pooled after desalting and then endotoxin removal was performed using an EndoClean ${ }^{\mathrm{TM}}$ Kit from BioVintage. The final protein preparation contained $<0.05$ endotoxin units $(E U) / \mu$ g as measured by the chromogenic Limulus ameobocyte lysate assay (Associates of Cape Cod, Inc). Samples in each step of the process were collected and later analyzed by SDS-

Table 2 Observed $\mathrm{m} / \mathrm{z}^{\mathrm{a}}$ values of the tryptic peptides derived from rcm-LALF $32-51$-E7 and their theoretical values calculated from the deduced sequence

\begin{tabular}{cccc}
\hline $\begin{array}{c}\text { Observed } \\
\mathbf{m} / \mathbf{z}\end{array}$ & $\begin{array}{c}\text { Theoretical } \\
\mathbf{m} / \mathbf{z}\end{array}$ & Charge & Sequence \\
\hline 411.70 & 411.70 & 2 & $2-7^{\mathrm{b}}$ \\
761.44 & 761.47 & 1 & $8-13$ \\
480.25 & 480.26 & 1 & $23-25$ \\
1396.20 & 1396.20 & 4 & $26-75$ \\
706.83 & 706.83 & 2 & $76-86$ \\
751.35 & 751.34 & 1 & $87-92$ \\
664.34 & 664.34 & 2 & $93-103$ \\
882.46 & 882.45 & 3 & $104-127$ \\
1124.60 & 1124.57 & 2 & $103-123$ \\
416.22 & 416.23 & 1 & $124-127$ \\
456.70 & 456.71 & 2 & $128-134^{\mathrm{c}}$ \\
\hline
\end{tabular}

ass to charge ratio.

${ }^{\mathrm{b}} \mathrm{N}$-terminal peptide.

${ }^{c} \mathrm{C}$-terminal peptide.
PAGE and Western blot. The MW of the recombinant protein was estimated using size exclusion analytic HPLC (YL9100) in a Superdex 200 10/300 GL column (GE Healthcare); briefly $200 \mu \mathrm{L}$ of the purified protein were applied at a flow rate of $0.5 \mathrm{ml} / \mathrm{min}$ in $10 \mathrm{mM}$ Tris (pH 8.0). MW was estimated using the retention times, in comparison with a gel filtration standard preparation (Bio-Rad).

\section{SDS-PAGE and Western blot}

SDS-PAGE (15\%) was performed according to Laemmli (Laemmli 1970). Protein expression and purity were evaluated by densitometry (TDI-1D manager 2.0 software, Spain) of SDS-PAGE gels. Proteins were visualized by Coomasie blue staining. The identity of the protein was verified by Western blot (Burnette 1981). Briefly, proteins were separated by SDS-PAGE and transferred to Hybond $\mathrm{C}$ extra nitrocellulose (Amersham Biosciences) in a semidry transfer unit (Bio-Rad). The membrane was blocked with $5 \%$ skimmed milk in PBS $(140 \mathrm{mM} \mathrm{NaCl}, 2.7 \mathrm{mM}$ $\mathrm{KCl}, 10 \mathrm{mM} \mathrm{Na}_{2} \mathrm{HPO}_{4}$ and $1.8 \mathrm{mM} \mathrm{KH}_{2} \mathrm{PO}_{4}$, $\left.\mathrm{pH} 7.4\right) / 0.1 \%$ Tween 20 (PBS-T) overnight at $4^{\circ} \mathrm{C}$. After three washes with PBS-T, the membrane was incubated for $2 \mathrm{~h}$ at $25^{\circ} \mathrm{C}$ with mouse anti-HPV-16 E7 monoclonal antibody (Abcam) diluted 1:1000 in blocking solution. The membrane was washed three times with PBS-T and further incubated for $1 \mathrm{~h}$ at $25^{\circ} \mathrm{C}$ with goat anti-mouse IgG antibodies conjugated with HRP (Sigma) diluted 1:5000 in blocking solution. After extensively washing with $\mathrm{PBS}-\mathrm{T}$, the antibody-reactive 
bands were detected with an enhanced chemiluminescence kit (Amersham Pharmacia Biotech).

\section{Transmission electron microscopy}

For ultrastructural studies the samples consisting of pelleted cells $\left(2 \times 10^{7}\right.$ cells $)$ from non-transformed or transformed BL21 (DE3) E. coli that express the recombinant fusion protein were fixed with $3.2 \%$ glutaraldehyde, and post-fixed for $1 \mathrm{~h}$ in $2 \% \mathrm{OsO}_{4}$. Then it was rinsed with $0.1 \mathrm{M}$ PBS, pH 7.2, and dehydrated in increasing ethanol concentrations such as $50 \%, 70 \%, 80 \%, 90 \%$ and $100 \%$. The embedding was in Spurr. The blocks were sectioned with an ultramicrotome (NOVA, LKB), and the ultrathin sections were placed on 400-mesh cooper grids. The ultrathin sections were stained with uranyl acetate and lead citrate and then examined in a JEOL-JEM 2000 EX electron microscope (JEOL, Japan).

For the negative staining studies, a drop of purified $\mathrm{LALF}_{32-51}$-E7 fusion protein was placed on to a 400-mesh copper grid coated with formvar-carbon film. Following $30 \mathrm{~min}$ of sample absorption and washing with water, grids were stained for $30 \mathrm{~s}$ with $2 \%$ uranyl acetate. After staining, grids were dried with Whatman no. 1 filter paper and allowed to air dry for $15 \mathrm{~min}$. Samples were then viewed on JEOL-JEM 2000 EX electron microscope.

\section{Reduction and S-carboamidomethylation of cysteines}

The LALF $_{32-51}$-E7 protein (10 nmoles) was dissolved in $100 \mathrm{ml}$ of $6 \mathrm{M}$ guanidium chloride, $500 \mathrm{mM}$ Tris, $\mathrm{pH}$ 8.1, and incubated for $2 \mathrm{~h}$ with dithiothreitol (DTT) 50-fold in excess over cysteines, in a nitrogen atmosphere at $37^{\circ} \mathrm{C}$. Iodoacetamide was added 2-fold over DTT, and the reaction proceeded at $25^{\circ} \mathrm{C}$ for $30 \mathrm{~min}$ in the dark. The reduced and fully alkylated protein (rcm-LALF $32-51-E 7$ ) was desalted by HPLC system (LKB-Phamacia, Sweeden) in a RP-C4 column $(4.6 \times 50 \mathrm{~mm}$, Vydac). The elution was performed with a linear gradient of solvent B $(0.05 \%$ TFA in acetonitrile) from 5 to $60 \%$ in $30 \mathrm{~min}$ at a flow rate of $0.8 \mathrm{ml} / \mathrm{min}$ (Solvent A, $0.1 \%$ TFA in water). The eluate was monitored at $226 \mathrm{~nm}$. An aliquot was submitted to ESI-MS analysis and the rest of the sample was evaporated under vacuum to dryness before trypsin digestion.

\section{Trypsin digestion}

The rcm-LALF $32-51$-E7 was reconstituted in 0.05\% $\mathrm{NH}_{4} \mathrm{HCO}_{3}$ buffer and digested with trypsin (Promega, USA) at enzyme-to substrate mass ratio $1: 50$ for $4 \mathrm{~h}$ at $37^{\circ} \mathrm{C}$.

\section{Mass spectrometry}

ESI-MS and MS/MS spectra were acquired using a hybrid quadrupole orthogonal acceleration tandem mass spectrometer QTOF-2 ${ }^{\text {TM }}$ from Micromass (Manchester, UK) fitted with a Z-spray nanoflow electrospray ion source.
Other measuring conditions and data processing were the same as reported previously (Gonzalez et al. 2003).

\section{Abbreviations \\ HPV: Human papillomavirus; KanR: Kanamycin resistance gene; MW: Molecular weight; SDS-PAGE: Sodium dodecyl sulfate polyacrilamide electrophoresis.}

\section{Competing interests}

The authors declare that they have no competing interests in relation to this article.

\section{Authors' contributions}

IT and MG conceive of the study and participated in its design and coordination and draft the manuscript. $A B, V L$ and $A M$ carried out the fermentation and purification of the recombinant protein. $M B$ participated in size exclusion analytic HPLC studies. RM and VF carried out the Transmission electron microscopy experiments. $L B, V B$ and $L J$ performed the Mass spectrometry studies. All authors participated in the preparation of the manuscript, and read and approved the final manuscript.

\section{Acknowledgements}

We thank Michel Díaz, Willy Frometa and Rocío Garateix for technical assistance. The research was supported by the Center for Genetic

Engineering and Biotechnology.

Received: 28 August 2012 Accepted: 8 January 2013

Published: 12 January 2013

\section{References}

Armstrong DJ, Roman A (1993) The anomalous electrophoretic behavior of the human papillomavirus type $16 \mathrm{E} 7$ protein is due to the high content of acidic amino acid residues. Biochem Biophys Res Commun 192:1380-1387

Barbosa MS, Edmonds C, Fisher C, Schiller JT, Lowy DR, Vousden KH (1990) The region of the hpv E7 oncoprotein homologous to adenovirus E1a and Sv40 large $T$ antigen contains separate domains for $\mathrm{R}$ binding and casein kinase II phosphorilation. EMBO J 9:153-160

Bolhassani A, Zahedifard F, Taghikhani M, Rafati S (2008) Enhanced immunogenicity of HPV16E7 accompanied by Gp96 as an adjuvant in two vaccination strategies. Vaccine 26:3362-3370

Burnette WN (1981) "Western blotting": electrophoretic transfer of proteins from sodium dodecyl sulfate-polyacrylamide gels to unmodified nitrocellulose and radiographic detection with antibody and radioiodinated protein A. Anal Biochem 112:195-203

Chart H, Smith HR, La Ragione RM, Woodward MJ (2000) An investigation into the pathogenic properties of Escherichia coli strains BLR, BL21, DH5alpha and EQ1. J Appl Microbiol 89:1048-1058

Chu NR, Wu HB, Wu T, Boux LJ, Siegel MI, Mizzen LA (2000) Immunotherapy of a human papillomavirus (HPV) type 16 E7-expressing tumour by administration of fusion protein comprising Mycobacterium bovis bacille Calmette-Guerin (BCG) hsp65 and HPV16 E7. Clin Exp Immunol 121:216-225

Gonzalez LJ, Castellanos-Serra L, Badock V, Diaz M, Moro A, Perea S, Santos A, Paz-Lago D, Otto A, Muller EC, Kostka S, Wittmann-Liebold B, Padron G (2003) Identification of nuclear proteins of small cell lung cancer cell line H82: An improved procedure for the analysis of silver-stained proteins. Electrophoresis 24:237-252

Granadillo M, Vallespi MG, Batte A, Mendoza O, Soria Y, Lugo VM, Torrens I (2011) A novel fusion protein-based vaccine comprising a cell penetrating and immunostimulatory peptide linked to human papillomavirus (HPV) type 16 E7 antigen generates potent immunologic and anti-tumor responses in mice. Vaccine 29:920-930

Harper DM, Franco EL, Wheeler CM, Moscicki AB, Romanowski B, Roteli-Martins CM, Jenkins D, Schuind A, Costa Clemens SA, Dubin G (2006) Sustained efficacy up to 4.5 years of a bivalent L1 virus-like particle vaccine against human papillomavirus types 16 and 18: follow-up from a randomised control trial. Lancet 367:1247-1255

Jana S, Deb JK (2005) Strategies for efficient production of heterologous proteins in Escherichia coli. Appl Microbiol Biotechnol 67:289-298

Jones RE, Wegrzyn RJ, Patrick DR, Balishin NL, Vuocolo GA, Riemen MW, DefeoJones D, Garsky VM, Heimbrook DC, Oliff A (1990) Identification of HPV-16 E7 
peptides that are potent antagonists of E7 binding to the retinoblastoma suppressor protein. J Biol Chem 265:12782-12785

Laemmli UK (1970) Cleavage of structural proteins during the asseembly of the head of bacteriophage T4. Nature 227:680-685

Liu B, Ye D, Song X, Zhao X, Yi L, Song J, Zhang Z, Zhao Q (2008) A novel therapeutic fusion protein vaccine by two different families of heat shock proteins linked with HPV16 E7 generates potent antitumor immunity and antiangiogenesis. Vaccine 26:1387-1396

Munger K, Werness BA, Dyson N, Phelps WC, Harlow E, Howley PM (1989) Complex formation of human papillomavirus E7 proteins with the retinoblastoma tumor supressor gene product. EMBO I 8:4099-4105

Munger K, Basile JR, Duensing S, Eichten A, Gonzalez SL, Grace M, Zacny VL (2001) Biological activities and molecular targets of the human papillomavirus E7 oncoprotein. Oncogene 20:7888-7898

Oyewumi MO, Kumar A, Cui Z (2010) Nano-microparticles as immune adjuvants: correlating particle sizes and the resultant immune responses. Expert Rev Vaccines 9:1095-1107

Preville X, Ladant D, Timmerman B, Leclerc C (2005) Eradication of established tumors by vaccination with recombinant Bordetella pertussis adenylate cyclase carrying the human papillomavirus 16 E7 oncoprotein. Cancer Res 65:641-649

Rosenberg AS (2006) Effects of protein aggregates: an immunologic perspective. AAPS J 8:E501-E507

Sorensen HP, Mortensen KK (2005) Advanced genetic strategies for recombinant protein expression in Escherichia coli. J Biotechnol 115:113-128

Williams JA, Carnes AE, Hodgson CP (2009) Plasmid DNA vaccine vector design: impact on efficacy, safety and upstream production. Biotechnol Adv 27:353-370

zur Hausen H (2002) Papillomaviruses and cancer: from basic studies to clinical application. Nat Rev Cancer 2:342-350

zur Hausen H (2009) Papillomaviruses in the causation of human cancers - a brief historical account. Virology 384:260-265

doi:10.1186/2193-1801-2-12

Cite this article as: Granadillo et al:: Expression, purification and

characterization of a recombinant fusion protein based on the human papillomavirus-16 E7 antigen. SpringerPlus 2013 2:12.

\section{Submit your manuscript to a SpringerOpen ${ }^{\circ}$ journal and benefit from:}

- Convenient online submission

- Rigorous peer review

- Immediate publication on acceptance

- Open access: articles freely available online

- High visibility within the field

- Retaining the copyright to your article

Submit your next manuscript at $\gg$ springeropen.com 